\title{
Toxicity of Cadmium and Nickel in Soil and Vegetables
}

\author{
Sunita Kumari ${ }^{1}$, Ashwani Chandrawal ${ }^{1}$, Manoj Kumar ${ }^{2 *}$ and Anand Kumar ${ }^{2}$ \\ ${ }^{1}$ Krishi Vigyan Kendra, Aurangabad (Bihar), India \\ ${ }^{2}$ Department of Plant Breeding and Genetics, Bihar Agricultural University, Sabour \\ (Bhagalpur)-813210, India
}

*Corresponding author

\section{A B S T R A C T}

\section{Keywords \\ Toxicity, Cadmium and Nickel, Soil and Vegetables \\ Article Info \\ Accepted: \\ 18 September 2018 \\ Available Online: \\ 10 October 2018}

Heavy metals like cadmium, nickel, lead, chromium, mercury etc are important environmental pollutants in areas with anthropogenic pressure. Their presence in the atmosphere, soil and water, even in traces can cause serious problems to all organisms. Heavy metal accumulation in soils is of great concern in agricultural production due to the adverse effects on food quality, crop growth (Ma et al., 1994) and environmental health. Heavy metal bioaccumulation in the food chain can be especially highly dangerous to human health.

\section{Cadmium concentration in soil}

The total concentration of $\mathrm{Cd}$ in soils was found to vary between 0.01 to $0.70 \mathrm{mg} \mathrm{kg}^{-1}$ as reported by Lindsay (1979). However, higher value to the extent of $2.44 \mathrm{mg} \mathrm{kg}^{-1}$ has also been reported by Wang Lixia (1979). The Cd concentration also increased with time. Mean $\mathrm{Cd}$ concentrations in soil increased form 1.13 $\mathrm{mg} \mathrm{kg}^{-1}$ in 1979 to $1.94 \mathrm{mg} \mathrm{kg}^{-1}$ in 1987 .

Cadmium in agricultural soil is likewise relatively immobile under normal conditions, but could become more mobile under certain conditions such as increased soil acidity and its cadmium level may be enhanced by the usage of phosphate fertilizers manure or sewage sludge (Table 1).

\section{Nickel concentration in soil}

Contributions of nickel to soil arise from both natural and man-made sources. Among the farmer are parent bedrocks deposits enriched in nickel, micrometeorites and cosmic dust. The last two are of relatively little importance. Man-made source of nickel include smelting of nickel ferrous areas, metal refining, burning of coal, burning of petroleum products, disposal of waste sewage and sludge and fertilizer applications. The effects of manmade sources on the nickel contents of soil in generally local, although in certain cases industrial and other man made plumes of pollution combined with unusual climate condition may, disperse nickel over large regions of the earth. 
The average nickel content of soil as given by Vinogradov (1959) is $40 \mathrm{mg} \mathrm{kg}^{-1}$. Swaine (1955) given a wide range from 5 to $500 \mathrm{mg}$ $\mathrm{kg}^{-1} \mathrm{Ni}$, our estimate of the average nickel content of soil calculated from a large number of analyses done in the Geological survey of Canada and those in the available world literature is $35 \mathrm{mg} \mathrm{kg}^{1}$.

According to Page (1974), heavy metal constitutes only $0.1 \%$ of the sludge solids but, its content in soil may be significantly raised through long term land application of sludge Mahdy et al., (2007) reported that application of biosolids increases DTPA-extractable nickel. The levels of extractable $\mathrm{Ni}$ reach to $25.12 \mathrm{mg} \mathrm{kg}^{-1}$ in clay soil at the highest application rate where as in sandy soil the levels of extractable $\mathrm{Ni}$ was $17.18 \mathrm{mg} \mathrm{kg}^{-1}$, while in calcareous soil it reached to $22.08 \mathrm{mg}$ $\mathrm{kg}^{-1}$ at the highest application rate.

\section{Cadmium concentration and uptake in different vegetables}

Cadmium is taken up from soil by the plant roots. The plants grown on soils that are very sandy, acidic and are low in organic matter more easily absorb cadmium in soil attaches to clay particles \& sandy soils with low clay content and organic matter induces higher uptake of cadmium. Lagarwerff (1971) studied $\mathrm{Cd}, \mathrm{Pb}$, and $\mathrm{Zn}$ uptake by radish grown on soil near a busy highway and observed a decrease in yield and metal content with increasing $\mathrm{pH}$. An increase in $\mathrm{Cd}$ uptake by eight food crops due to the application of $\mathrm{CdCl}_{2}$ has been reported by John (1973). The result was supported by Jone et al., (1973) who showed that $\mathrm{Cd}$ either in salt form or sludge borne was readily available to soybean but never observed seed. Cd levels more than $1 \mathrm{mg} \mathrm{kg}$ ${ }^{1}$ with addition of $87.1 \mathrm{mt} \mathrm{ha}{ }^{-1}$ of digested sludge containing $129 \quad \mathrm{mg} \quad \mathrm{kg}^{-1} \mathrm{Cd}$. Satyaprakash (1992) reported that all crop species accumulated higher amount of $\mathrm{Cd}$ in their roots. Considering the average value, the
Cd accumulation in different crop species was found in the order: Potato $>$ Toria> Cauliflower $>$ Faba bean $>$ Cabbage> Amaranthus. Guttormsen et al., (1995) were conducted field trails over three year period with Chinese cabbage and carrots grown in a sandy soil. The NPK fertilizers containing 1, 30,90 and $400 \mathrm{mg} \mathrm{Cd} \mathrm{kg}^{-1} \mathrm{P}$ were applied at the rate of $0.07,2.1,6.3$ and $28 \mathrm{~g} \mathrm{Cd} \mathrm{ha}^{-1} \mathrm{yr}^{-1}$. The amounts of $\mathrm{Cd}$ added through phosphate rock also ranged between 0.1 and $28 \mathrm{~g} \mathrm{ha}^{-1}$ $\mathrm{yr}^{-1}$. The increased $\mathrm{Cd}$ application rates through NPK fertilizers increased the $\mathrm{Cd}$ concentration in both vegetables. The $\mathrm{Cd}$ uptake by both crops was significantly higher. Chinese cabbage exhibited lower $\mathrm{Cd}$ concentration than carrots. Carrot leaves contained higher $\mathrm{Cd}$ than its roots. Cadmium removals by Chinese cabbage and carrot were about 0.7 and $1.3 \mathrm{~g} \mathrm{ha}^{-1} \mathrm{yr}^{-1}$, respectively. At $\mathrm{pH} 5.5, \mathrm{Cd}$ concentrations in the two crops, based on a three year average, were 23 and $46 \%$ higher than at $\mathrm{pH}$ 6.5. Cadmium uptake by Chinese cabbage from different sources of phosphate rock was affected to a very limited extent. Cadmium concentration generally increased over the years. Cadmium concentration in shoots and roots varied both with different cadmium levels and type of vegetables. Generally cadmium accumulations in various plant parts in vegetables crops increased with the increasing cadmium concentration in the growth medium. Root cadmium increased more sharply than shoot cadmium. Celery contained higher $\mathrm{Cd}$ in the edible parts than other vegetable species (Ni et $a l .$, 2002). The cadmium concentration in each of the three parts varied with the level of cadmium and highest being in treatment receiving $100 \mathrm{mg} \mathrm{kg}^{-1} \mathrm{Cd}$. In this treatment, the level of cadmium accumulation in the stem, leaf and root was 3.36, 2.60 and $1.78 \mathrm{mg}$ $\mathrm{kg}^{-1}$ dry weight, respectively. The results also show that $\mathrm{Cd}$ accumulation was the least in the root and most in the stem of all species (Table 2 and 3$)$. 
Nickel concentration and uptake in different vegetables

Banin et al., (1981) reported higher content of $\mathrm{Ni}$ in plant with sewage water application than irrigation water and explained that the uptake of a given element appeared to be largely determined by its solubility in the soil solution and can be generally predicted by its ionic strength. Sailed and Kardos (1977) suggested that crop tolerance to $\mathrm{Ni}$ application varied with plant species and metal species. The Ni content of most species of vegetables usually didn't exceed $10 \mu \mathrm{g} \mathrm{g}^{-1}$ except for taxa growing on nickel rich soils where $10-100 \mu \mathrm{g}$ $\mathrm{g}^{-1} \mathrm{Ni}$ level was common. Use of $\mathrm{Ni}$ up to 125 $\mathrm{mg} \mathrm{kg}{ }^{-1}$ increased Ni content in alfalfa but did not exert pronounced influence on yield depression. $250 \mathrm{mg} \mathrm{kg}^{-1} \mathrm{ppm} \mathrm{Ni}$ treatment significantly increased $\mathrm{Ni}$ content and depressive effect on alfalfa yields (Taylor and Allinson, 1981). The Ni content in alfalfa varied from 0.5 to $9.4 \mathrm{mg} \mathrm{kg}^{-1}$ however, 300 $\mathrm{mg} \mathrm{kg}{ }^{-1} \mathrm{Ni}$ in plants was recorded with the addition of $200 \mathrm{mg} \mathrm{kg}^{-1} \mathrm{Ni}$ in soil. The linear relationship between $\mathrm{Ni}$ uptake by plants and the amount of applied $\mathrm{Ni}$ was reported (Valdares et. al., 1983). The maximum concentration of metal was found in spinach leaves followed by berseem, cauliflower and maize leaves, while the cauliflower heads had the lowest concentration (Kansal and Singh, 1983). The highest Ni contents was found in roots. Plant grown in pots absorbed more $\mathrm{Ni}$ than from the same soils in the field. The uptake of $\mathrm{Ni}$ in the shoots of all the crops increased significantly with increasing levels of $\mathrm{Ni}$ application. The nickel uptake in spinach increased from $19.4^{\mu} \mathrm{g}$ pot in control to 37.0.2 ${ }^{\mu} \mathrm{g} \mathrm{pot}^{-1}$ with $80 \mathrm{mg} \mathrm{kg}^{-1}$ soil but at higher levels of $\mathrm{Ni}$ application, there was decrease in Ni uptake. Similarly Ni uptake in fenugreek and coriander increased upto 60 and $120 \mathrm{mg} \mathrm{kg}^{-1}$ soil application and showed decreasing trend there after (AR MNS, Ludhiana 2004-05). Kumar (2005) reported that the Ni-concentration in different vegetable crops depended on the distance of the cropped site with respect to discharge point of sewage-sludge. Higher $\mathrm{Ni}$ concentration in different crop species grown on sewage irrigated soils were obtained as compared to those grown on the ground water irrigated soils. Different plant species varied in their $\mathrm{Ni}$ concentration in the sequence; Potato> Toria> Cauliflower> Amaranthus> Cabbage.

The Nickel uptake by corn plants was significantly increased at all application rates in all soil studies and the corn plants grown in the clay soil had a higher assimilative capacity for uptake of Ni than other soils. The uptake values of heavy metals followed the following order; clay > calcareous > sandy soils. The $\mathrm{Ni}$ concentrations in all plant parts were higher in the biosolids treatment than in the control for all soils. Nickel concentration accumulated in parts of corn plants in the following order: roots> shoots. In general, application of biosolids significantly increased $\mathrm{Ni}$ concentration in shoots and roots of corn plants grown in all studies soils. The increase in Ni concentration peaked at the high level of biosolids application rate (3\%) (Mahdy et al., 2007) (Table 4-7).

\section{Response of cadmium application}

Bingham et al., (1976) reported that soybean is most Sensitive crop where 25\% reduction in yield by the soil application of as low as 5 to $15 \mathrm{ppm} \mathrm{Cd}$. An increase in $\mathrm{Cd}$ content in soybean seed has also been reported by Ham and Dowdy (1978) due to sludge application. They observed that $\mathrm{Cd}$ addition through inorganic salt did not affect soybean yield but increased its concentration in soybean seed. Addition of cadmium to the soil lowered the dry matter yield of ryegrass and also reduced the yield of oat grain as reported by Allison and Dzialo (1980). 
Table.1 The contamination level of trace elements in rural soils of the world

\begin{tabular}{|c|c|c|c|c|c|c|c|}
\hline Country & Australia & China & S. Africa & U.K & U.S.A & Japan & Taiwan \\
\hline $\begin{array}{c}\text { Cd Con. } \\
\left(\mathrm{mg} \mathrm{kg}^{-1}\right)\end{array}$ & 1 & 20 & 2 & 3 & 38 & - & 4 \\
\hline
\end{tabular}

Source: Chan et al., 1999.

Table.2 Major anthropogenic inputs of Cd to soil are following

\begin{tabular}{|r|l|c|c|}
\hline \multicolumn{1}{|c|}{$\begin{array}{c}\text { Source of Cd } \\
\text { A }\end{array}$} & $\begin{array}{c}\text { Concentration in soil } \\
\left(\mathrm{mg} \mathrm{kg}^{-1}\right)\end{array}$ & Input to soil $\left(\mathrm{kg} \mathrm{ha}^{-1} \mathrm{yr}^{-1}\right)$ \\
\hline $\mathbf{1}$ & Wet/dry deposition general & - & $<1.1-9.0$ \\
\hline 2 & $\begin{array}{l}\text { Wet/dry deposition general } \\
\text { smelters }\end{array}$ & - & $25-1000$ \\
\hline B & Street dust & $1.5-12$ & - \\
\hline C & Rubber tyre wear & $20-90$ & - \\
\hline D & Incinerator fly-ash & $2.6-68$ & - \\
\hline E & Direct application & $0.2-345 / 1.0-641$ & $0.3-8.9 /-$ \\
\hline i & P-fertilizer & $<6.0$ & - \\
\hline ii & By product gypsum & $<1-3410$ & Up to 150 \\
\hline iii & Sewage-sludge & $0.26-11.7$ & - \\
\hline Iv & Compost & & \\
\hline
\end{tabular}

Source: McLaughlin and Singh, 1999

Table.3 Maximum permissible concentration of $\mathrm{Cd}$ in sludges and sludge treated agricultural soils in different countries

\begin{tabular}{|c|c|c|c|c|}
\hline Country & year & $\begin{array}{c}\text { Maximum } \\
\text { concentration in } \\
\text { sludges (mg Cd kg } \\
\text { dm) }\end{array}$ & $\begin{array}{l}\text { Concentration } \\
\text { in sludge } \\
\text { treated soil (mg } \\
\mathrm{Cd} \mathrm{kg}^{-1} \text { ) }\end{array}$ & $\begin{array}{c}\text { Annual } \\
\text { loading limit } \\
\mathrm{kg} \mathrm{Cd} \mathrm{ha}^{-1} \mathrm{yr}^{-1}\end{array}$ \\
\hline $\mathbf{E U}$ & 1986 & $20-40$ & $1-3$ & 0.15 \\
\hline France & 1988 & 20 & 2.0 & 0.15 \\
\hline Germany & 1992 & 10 & 1.5 & 0.15 \\
\hline Spain & 1990 & 20 & 1.0 & 0.15 \\
\hline Denmark & $1990 / 95$ & $1.2 / 0.8$ & 0.5 & 0.008 \\
\hline Finland & 1995 & 1.5 & 0.5 & 0.0015 \\
\hline Sweden & 1995 & 2.0 & 0.5 & 0.002 \\
\hline U.K. & 1989 & - & 3.0 & 0.15 \\
\hline USA & 1993 & 85 & 20 & 1.9 \\
\hline
\end{tabular}

Source: Mc Grath et al., (1994) 
Table.4 Heavy metals concentration in soils of Bihar

\begin{tabular}{|c|c|c|c|c|c|}
\hline District & & $\mathrm{Pb}(\mathrm{ppm})$ & Ni(ppm) & Cd(ppm) & $\mathrm{Co}(\mathrm{ppm})$ \\
\hline \multirow[t]{2}{*}{ Saharsa } & Mean & 1.87 & 4.51 & 0.05 & 0.65 \\
\hline & Range & $0.05-4.28$ & $0.40-12.36$ & $0.00-0.15$ & 0.12-1.27 \\
\hline \multirow[t]{2}{*}{ Madhepura } & Mean & 2.63 & 6.40 & 0.02 & 0.48 \\
\hline & Range & $0.07-8.36$ & $0.14-11.35$ & $0.00-0.06$ & $0.01-1.00$ \\
\hline \multirow{2}{*}{ Begusarai } & Mean & 1.52 & 4.15 & 0.05 & 0.55 \\
\hline & Range & $0.42-2.90$ & $0.20-9.81$ & 0.01-0.09 & $0.07-1.36$ \\
\hline \multirow[t]{2}{*}{ Bhagalpur } & Mean & 2.05 & 4.86 & 0.39 & 1.41 \\
\hline & Range & $0.90-3.88$ & $3.02-29.01$ & $0.11-0.91$ & $0.04-4.14$ \\
\hline \multirow[t]{2}{*}{ Purnea } & Mean & 0.51 & 5.31 & 0.09 & 0.22 \\
\hline & Range & $0.02-1.72$ & $1.26-9.05$ & $0.00-0.17$ & $0.00-0.48$ \\
\hline \multirow[t]{2}{*}{ Dharbhanga } & Mean & 1.20 & 5.42 & 0.03 & 0.55 \\
\hline & Range & $0.37-5.08$ & $0.07-9.99$ & $0.01-0.40$ & $0.24-0.78$ \\
\hline \multirow[t]{2}{*}{ Patna } & Mean & 0.80 & 4.29 & 0.03 & 1.56 \\
\hline & Range & $0.04-2.10$ & $0.06-9.87$ & $0.00-0.09$ & $0.03-3.96$ \\
\hline \multirow[t]{2}{*}{ Vaishali } & Mean & 0.56 & 3.35 & 0.03 & 0.84 \\
\hline & Range & $0.02-1.20$ & $1.09-10.21$ & $0.02-0.05$ & $0.45-1.16$ \\
\hline \multirow[t]{2}{*}{ Muzaffarpur } & Mean & 0.87 & 5.59 & 0.30 & - \\
\hline & Range & $0.38-1.55$ & $2.14-9.92$ & $0.26-0.37$ & - \\
\hline \multirow[t]{2}{*}{ Samastipur } & Mean & 0.78 & 0.25 & 0.07 & 0.37 \\
\hline & Range & $0.12-2.47$ & $0.10-0.48$ & $0.04-0.15$ & $0.24-0.50$ \\
\hline
\end{tabular}

Source: Annual Report (MNS), 2007-08

Table.5 Sources of concentration of $\mathrm{Ni}$ in soil through fertilizers, animal manures and minerals

\begin{tabular}{|l|l|}
\hline \multicolumn{1}{|c|}{ Source } \\
\hline A. Fertilizer \\
\hline Nitrogen \\
\hline Phosphorous \\
\hline Potassium \\
\hline Mixed compounds \\
\hline B. Animal sources \\
\hline Animal wastes \\
\hline Cattle manure \\
\hline Poultry waste \\
\hline Pig waste \\
\hline Farmyard manure \\
\hline Cow manure \\
\hline C. Mines \\
\hline Coal \\
\hline Lignite \\
\hline Flash \\
\hline
\end{tabular}

\begin{tabular}{|c|}
\hline Nickel $\left(\mathrm{mg} \mathrm{kg}^{-1}\right)$ \\
\hline tr -80 \\
\hline $\operatorname{tr}-300$ \\
\hline $\operatorname{tr}-80$ \\
\hline $\operatorname{tr}-800$ \\
\hline $\operatorname{tr}-130$ \\
\hline- \\
\hline- \\
\hline- \\
\hline 17 \\
\hline 29 \\
\hline 15 \\
\hline 13 \\
\hline 12.8 \\
\hline
\end{tabular}

Source: Robert and Boyle, 1988. 
Table.6 Average and/or range of nickel content of natural waters, precipitates from natural waters and drainage sediments

\begin{tabular}{|l|c|}
\hline \multicolumn{1}{|c|}{ Description } & Ni content $\left(\mathrm{mg} \mathrm{kg}^{-1}\right)$ \\
\hline Rain water and snow & Up to 0.001 \\
\hline Hot springs & $\mathbf{0 . 0 0 0 5 - 0 . 4}$ \\
\hline Ground waters, cold spring and mine waters & $\mathbf{0 . 0 0 0 - 4 . 5}$ \\
\hline Stream, river and lake waters & $\mathbf{0 . 0 0 0 5 - 4 . 5}$ \\
\hline Ocean and sea waters & $\mathbf{0 . 0 0 1 5}$ \\
\hline Normal Fe-Mn precipitates (dry matter) from spring & $\mathbf{7 - 1 0 0}$ \\
\hline Stream and river sediments (dry matter) & $\mathbf{1 - 1 5 0}$ \\
\hline
\end{tabular}

Source: Robert and Boyle, 1988.

Table.7 Nickel contents $\left(\mathrm{mg} \mathrm{kg}^{-1}\right)$ in some vegetables grown on dry riverbed of Ganges

\begin{tabular}{|c|c|}
\hline Vegetable & Nickel $\left(\mathrm{mg} \mathrm{kg}^{-1}\right)$ \\
\hline Bottle gourd & 1.1 \\
\hline Bitter gourd & 15.5 \\
\hline Garden spinach & 13.2 \\
\hline Radish & $\mathbf{1 0 . 1}$ \\
\hline Snake cucumber & 4.2 \\
\hline Sponge gourd & $\mathbf{7 . 5}$ \\
\hline Tinda & $\mathbf{8 . 2}$ \\
\hline
\end{tabular}

Source: Farooq et al., (2000).

Table.8 Permissible limits of cadmium

\begin{tabular}{|c|c|c|c|}
\hline Element $\left(\mathrm{mg} \mathrm{kg}^{-1}\right)$ & Deficient & high & Excessive/Toxic \\
\hline Cadmium & $0.5-1.0$ & $1-2$ & 2 \\
\hline
\end{tabular}

Source: AR (MNS), Haryana, 2001-02

Poschenrieder et al., (1983) conducted an experiment in nutrient culture with $0,10,80$ or $160 \mathrm{ppm}, \mathrm{Cd}$ and it was observed that plant growth, pigment (chlorophyll + carotenoid) content, seed number and size and protein content of $P$. vulgaris were reduced by $\mathrm{Cd}$. There was no effect on germination up to 80 $\mathrm{mg} \mathrm{kg}^{1} \mathrm{Cd}$. Increasing levels of cadmium in soil significantly decreased the mean shoot dry matter yield of wheat from 20.20 to 5.47 $\mathrm{g} /$ pot when levels of cadmium were increased from 0 to $200 \mathrm{mg} \mathrm{kg}^{-1}$ soil. The percent decrease in mean shoot dry matter yield of wheat was 72.9 at $200 \mathrm{mg} \mathrm{Cd} \mathrm{kg}^{-1}$ soil over control (AR MNS, Haryana 2002-03). Shentu et al., (2008) in a greenhouse experiment on three vegetable crops (Pakchoi, tomato and radish), observed that shoot growth was not inhibited by $\mathrm{Cd}$ except for radish grown on red yellow soil. A small amount of $\mathrm{Cd}$ stimulated growth of the vegetables.

\section{Response of nickel application}

No reduction in yield of crops grown on calcareous soil up to $200 \mathrm{ppm} \mathrm{Ni}$ application along with sludge was observed by Valdares et al., (1983) and it was suggested that the 
acceptable sludge load in the calcareous soil may be predicted by metal uptake. The poor correlation between yield and applied heavy metal was observed. Nadia et al., (2007) found that nickel improved shoot and root growth of tomato compared with control. Adding 15 and $30 \mathrm{mg} \mathrm{kg}^{-1}$ soil caused significantly increase in tomatoes fresh and dry weights of shoots and roots. These increases were found in the two seasons over that of untreated plants or those received 45

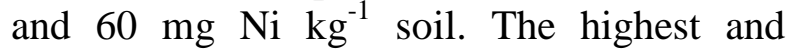
significant increase was obtained with $30 \mathrm{mg}$ $\mathrm{Ni} \mathrm{kg}{ }^{-1}$ soil. On the other hand, higher nickel concentration, namely 45 and $60 \mathrm{mg} \mathrm{Ni} \mathrm{kg}^{-1}$ soil, resulted in significant reduction in tomato, fresh \& dry weight. The vegetables (Okra, lettuce and pepper) did not show visible sign of physiological disorder and the growth rates for higher concentration of metal were comparable to the control suggesting that they tolerated the metals up to a concentration of $100 \mu \mathrm{g} \mathrm{dm}^{-3}$.

\section{Critical level of toxicity of cadmium}

The increasing problem of environmental pollution by heavy metals necessitates study on the toxicity of heavy metals to plants and subsequently to animals and human health. The toxicity of heavy metals to crop plants varied from metal to metal (Chino and Kitagishi, 1996) and from crop species in witch rice appeared to be most tolerant species (Tanaka et. al., 1975; Bingham et. al., 1976) Reduction in crop growth and yield are generally indicative symptoms of metal toxicity in plants. Heavy metal phytotoxicity has been demonstrated with plants grown in solution culture (Page et. al., 1972; Turner, 1973), greenhouse experiments (Bingham et al., 1975 Cunningham et al., 1975) and in field experiments (King and Morris, 1972).Cadmium was found to be most toxic for lettuce and wheat followed by $\mathrm{Ni}$ (Mitchell et al., 1978). Cadmium toxicity depend on plant species metal concentration range. At relatively low soil treatments $\mathrm{Cd}$ was more toxic to lettuce grown in calcareous soil than in acid soil. As reported by Chino (1981) the Cd toxicity symptom in rice is characterized by usually decrease in number of tillers and root growth is severely depressed. He recorded the toxicity levels of $\mathrm{Cd}$ in rice leaves as $5-10 \mathrm{mg} \mathrm{kg}^{-1}$ whereas those in rice root were $100-600 \mathrm{mg} \mathrm{kg}^{-1}$. A pot experiment was conducted to study the effect of $\mathrm{Cd}$ concentration on the yield of wheat and soybean and evaluated the phytotoxicity limit (Singh and Rattan, 1987). The guideline value for cadmium content in agriculture soils is $5.0 \mathrm{mg} \mathrm{kg}$. The WHO standard for cadmium in food items is 0.07 $\mathrm{mg} \mathrm{day}^{-1}$ (WHO, 1992). In a duplicate study, Cd intake amounted to $10 \mathrm{ug} \mathrm{day}^{-1}$ in men and to $9 \mathrm{ug} \mathrm{day}^{-1}$ in women, which is only 12 and $15 \%$ of the WHO limit value, hence it follows that the $\mathrm{Cd}$ exposure of soils and flora is not reflected in the food chain of the inhabitations of Bad Liebenstein and health risks caused from $\mathrm{Cd}$ can excluded (Muller and Anke, 1994) (Table 8).

\section{Critical level of toxicity of nickel}

Although $\mathrm{Ni}$ is a such an element for which phytotoxicity is seldom observed and there is no danger of entry into food chain in toxic amounts and ruminants tolerates at least 50 $\mathrm{mg} \mathrm{kg}^{-1} \mathrm{Ni}$ (NRC, 1980), however, forage crop show visual symptoms of toxicity at 50-100 $\mathrm{mg} \mathrm{kg}^{-1}$ level. Cattle suffered no effects from forage diets with $250 \mathrm{mg} \mathrm{Ni} \mathrm{kg}{ }^{-1}$ as $\mathrm{NiCO}_{3}$, while soluble $\mathrm{Ni}$ salts caused the animals to reduced food consumption. Reduction in yield of rye grass with $\mathrm{Ni}$ application beyond 30 $\mathrm{mg} \mathrm{kg}{ }^{-1}$ in soil was reported by Khalid and Tinaley (1980) who observed that leaf concentration of $50 \mu \mathrm{g} \mathrm{Ni} \mathrm{g}{ }^{-1}$ was not sufficient to reduce the yield, though slight chlorosis did appear at this level. Hofer and Schutz (1980) also observed that $50 \mathrm{mg} \mathrm{kg}^{-1}$ 
of $\mathrm{Ni}$ application reduced the oats grain and straw yield by 39 and $50 \%$, respectively and that of potato tuber by $65 \%$ causing leaf chlorosis and reduction in plant growth. However, Wallace (1980) observed that when $100 \mathrm{mg} \mathrm{Ni} \mathrm{kg}{ }^{-1}$ was added, maize showed sever toxicity symptoms and all the metal concentration in leaves were highest for this treatment. It was further reported that roots tended to concentrate in the non-contaminated part of the soil. In a similar study, Wallace (1989) observed that barley was most tolerate among maize, barley and soybean of the trace metals and yield depression occurred with this crop only when six metals were applied simultaneously, probably because of the metal induced P-deficiencies. Davis and Beckett (2006) reported that, though the concentration of $\mathrm{Cu}, \mathrm{Ni}$ or $\mathrm{Zn}$ in the tissue of young (five leaf) spring barley grown in nutrient solution containing one of the elements varies considerably with the growing conditions, the minimum concentration of $\mathrm{Cu}, \mathrm{Ni}$ or $\mathrm{Zn}$ in plant tissue ( $\mathrm{Cu}$ 19, Ni 12, Zn $210 \mathrm{mg} \mathrm{kg}^{-1}$ dry weight) necessary to cause toxic reactions are relatively independent of the growing conditions.

\section{Effect of organic matter availability and utilization of cadmium and nickel by crops}

Experiment conducted at Hisar (AR MNS, Hissar 2002-03) revealed that Ni uptake by wheat shoot decreased with the application of FYM, but significant decrease were observed only at 3 and 4 per cent FYM levels when compared with control. A significant decrease in $\mathrm{Ni}$ uptake by wheat shoot was also observed between 3 and 4 per cent FYM levels. The interaction effect of Ni X FYM with respect to Ni uptake by wheat shoot was found to be significant. Data again reveal that in the control soil (without FYM), Ni uptake

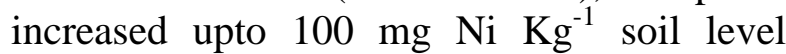
thereafter it decreased and likewise in case of 4 per cent FYM soil it increased upto $200 \mathrm{mg}$
$\mathrm{Ni} \mathrm{kg}{ }^{-1}$ soil level because of increased shoot dry matter yield in later soil and decreased in former soil. They further added that the application of FYM significantly decreased the Cd uptake by wheat shoot over control (no FYM). The mean Cd uptake by wheat shoot decreased from 401.68 to $358.63 \mu \mathrm{g}$ pot $^{-1}$ when levels of FYM in soil were increased from 0 to 4 per cent. The per cent decrease in Cd uptake by wheat shoot was 10.7 due to application of 4\% FYM when compared over control. The interaction effect of $\mathrm{Cd} \times \mathrm{FYM}$ with respect to $\mathrm{Cd}$ uptake by wheat shoot was found to be non-significant. Gondek et al., (2008), reported that the mean cadmium content in oat dry matter (from the three years of the experiment) depend on plant organ and applied fertilization. The highest cadmium content was detected in the roots. While in case of Nickel on the basis of results obtained no excessive accumulation of $\mathrm{Ni}$ in organs of plants fertilized with composts was detected, which resulted from its small concentration in composts.

\section{References}

Adhikari, A. Mitra; S.K. Gupta and S.K. Banerjee 1998. Pollutant metal content of vegetables irrigated with sewage water. $J$. Indian Soc. Soil Sci., 46: 153-155.

Allinson, D.W. and Dzialo, C. (1981). Springer Link Journal Article.

Alvarez, V.P; Corts, M.J; Ferrada, T.D; Leyton, M.C. and Sans, P.J. 1995. Experimental determination of the upper critical limit of tolerance for four heavy metals $(\mathrm{Cd}, \mathrm{Pb}$, $\mathrm{Mo}$ and $\mathrm{Cu}$ ) in adventitious roots of onion bulbs, Allium cepa L. Agricultura Tecnica Santiago. 55 (2): 86-94.

Annual Report, MNS 2007-08. Deptt. of Soil science, R.A.U., Pusa, Bihar.

Azad, A.S. 1981. Pollution of agricultural lands from sewage and industrial wastes. Ph.D. thesis, Punjab Agricultural University, Ludhiana, Punjab. 
Bahmanyar, M.A. 2008. Cadmium, Nickel, Chromium and Lead levels in Soils and Vegetables under Long-Term Irrigation with Industrial water. Communications in Soil science and Plant Analysis, 39 (13 \& 14): 2068-2079.

Banin, A.; Navrot, J.; Noi, Y. and Yoles, D. 1981. Accumulation of heavy metals in Arid zone soils irrigated with treated sewage effluents and their uptake by Rhodes Grass. J. Environ. Qual. 10: 536540.

Bingham, F.T; Page, A.L; Mahler, R.J. and Ganje, T.J. 1975. Growth and Cadmium accumulation of Plants grown on a soil treated with a cadmium enriched sewage sludge. J. Environ. Qual., 4: 207-211.

Brown, S.L; Chaney, R.L; Lioyd, C.A; Angle, J.S. and Ryan, J.A. 1996. Relative uptake of cadmium by garden vegetables and fruits grown on long-term biosolidamended soils. Environmental science and Technology. 30 (12): 3508-3511.

Chan et al., 1999. The contamination level of trace elements in rural soils of the world.

Chang, Ed-Haun; Chung, Ren-shin and Wang, Fei-Neng 2008. Effect of different types of organic fertilizers on the chemical properties and enzymatic activities of an oxisol under intensive. Cultivation of vegetables for 4 years. Soil Science and Plant Nutrition. 54 (4): 587-599.

Cunningham, J.D.; Keeney, D.R. and Ryan, J.A. 1975. Phytotoxicity and uptake of metals added to the soils as inorganic salts or in sewage sludge. J. Environ. Mual.4 460-462.

Davis, R.D. and Becket H.T. 2006. Upper critical levels of toxic elements I plants. New Phytolosist 80 (1): 23-32.

Davis, R.Q. C.H. Carlton-Smith., J.H. Stage and J.A. Compbell 1988. Distribution of metals in grassland soils following surface applications of sewage sludge. Environ. Pollut. 49: 99-115.

Dijkshoorn, W.; Lampe, J.E.M. and Van Broekhoven, L.W. 1981. Influence of soil $\mathrm{pH}$ on heavy metals in ryegrass from sludge-amended soil Neth. J. Agric. Sci. 29: 277-284.

Farooq, M.; Hans, R.K.; Viswanathan, P.N. and Joshi, P.C. 2000. Bull. Environ. Contam. Toxoid 62: 555-562, c.f. Rattan, R.K.; Datta, S.P. Chandra, Suresh and Saharan Neelam (2002). Heavy metal and environmental quality, fertile. News, 77 (11): 26-70.

Foy, C.D.; Chaney, R.L. and white, M.C. 1978. The physiology of metaltoxicity in plants. Ann. Rev. Plant Physiol. 29: 511-566.

Giordani, C., Cecchi, S. and Z. Camillo 2005. Phytre mediation of soil polluted by Nickel using Agricultural Crops. Environmental Managmeent.36 (5): 675 681.

Guttormsen, G; Singh, B.R. and Jeng, A.S. 1995. Nutrient cycling in Agroecosystems. 41 (1): 27-32.

Haghiri, F. 1973. Cadmium uptake by plants. $J$. Environ. Qual., 2: 93-96.

Haliru, M.; Ajibola, V.O. and Agbaji, E.B. 2009. Evaluation of the uptake and accumulation of metals by some commonly irrigated vegetables in soils treated with different concentrations of these metals. Journal of Applied Sciences, 9 (8): 1573-1577.

Hofer, H. and E. Schutz 1980. Contribution to the determination of threshold toxicity levels for heavy metals in plant production. Mitteilungen for die schweize-rische Landwirtschaft. 28: 6577 (c.f. Soil and fert. 44:5933).

Jackson, I. 1967. Soil Chemical analysis, Prentice hall of India, Pvt. Ltd., New Delhi, India.

Jackson, I. 1973. Soil Chemical analysis, Prentice hall of India, Pvt. Ltd., New Delhi, India.

Jiali Shentu, Zhenli He, XiGo. E. Yand and Tinggiang $\mathrm{Li}$ 2008. Accumulation properting Rotation system of South eastern China. J. Agric. Food chem., 56 (15): 6382-6388.

John, M.K. 1973. Cadmium uptake of eight food crops as influenced by various soil levels of cadmium. environ. Pollutt. 7-15. 
Jone, R.L.; Hinesly, T.D. and Ziegler, E.L. 1973. Cadmium contents of soybeans grown in sewage sludge amended soil. $J$. Environ. Qual., 3: 351-353.

Kansal, B.D. and Singh, J. 1983. Influence of municipal Wastes, Water and Soil properties on the accumulation of heavy metal in plants. Heavy metals in the environment 1: 413-416.

Khalid, B.Y. and Tinsley, J. 1980. Some effects of Nickel toxicity on rye grass. $\mathrm{Pl}$. soil 55: 139-144.

King, L.D. and Morris, M.D. 1972. Land disposal of liquid sewage sludge, 2 . The effect on soil $\mathrm{pH}$, manganese, Zinc and growth and chemical composition of rye. J. Envir. Qual., 1: 425-429.

Kumar Sharma R, Agrawal, M and Marshall, F. 2006. Heavy metal contamination of soil and vegetables in suburban areas of Varanasi, India. Ecotoxicol Environ. 66 (2): 258-66.

Kumar, V. 2005. Ph.D. thesis Deptt. of Soil Science, RAU, Pusa, Bihar.

Lagerqwerff, J.V. 1971. Uptake of $\mathrm{Cd}, \mathrm{Pb}$ and Zn by radish from soil-air. Soil Sci. III: 129-133.

Lal, K; Minhas, P.S; Chaturvedi; R.K. and Yadav, R.K. 2008. Cadmium uptake and tolerance of three aromatic Grasses on $\mathrm{Cd}$ rich Soil. Journal of the Indian Society of Soil science. 56 (3): 290-294.

Levin, M.B.; Hall, A.T.; Barrett, G.W. and Taylor, D.H. (1989). Heavy metal concentrations during ten years of sludge treatment to an old-field community. $J$. Environ. Qual., 18: 411-418.

Lindsay, W.L. 1979. Chemical equilbria in soils. John Willey, New York Chap. 15.

Lindsay. W.L. and Norvell, W.A. 1978. Deevelopment of DTPA Soil test for Zn, Fe, Mn and Cu. Soil Sci. Soc. Am. J. 42: 421-428.

Luzzati, A. and Siragusa, N. 1985-86. The effect of increasing additions of nickel on plant growth and concentrations of nickel and nutrient elements in five plant species. Annali dell Instituto
Sperimentale per la Nutrizione delle piante, Italy. XIII (4): 28.

Ma, Q.Y; Traina, S.J; Logan, T.J. 1994. Effect of aqueous $\mathrm{Al}, \mathrm{Cd}, \mathrm{Fe}(11), \mathrm{Ni}$ and $\mathrm{Zn}$ on $\mathrm{Pb}$ immobilization by hydroxyapatite. Environ, Sci. Technol. 28 (7): 1219-1228.

Mahdy, A.M; Elkhatib, E.A. and Fathi, N. O. 2007. Cadmium, Copper, Nickel and Lead Availability in Biosolids amended Alkaline Soils. Australian Journal of Basic and Applied Sciences, 1 (4): 354363.

Mc Grath S.P; Chang, A., Page, A.L. and Witter, E. 1994. Application of Swage sludge: scientific perspectives of heavy metal loading limits in Europe and the United States. Environ. Rev. 2: 108-118.

McLaughlin, M.J. and Singh, B.R. 1999. Major anthropogenic inputs to soils. Cadmium in soils and plants.

McLean, K.S; Robinson, A.R. and Mac. Cannell, H.M. 1987. The effect of sewage sludge on the heavy metal content of soil and plant tissue. Common Soil Sci. Plant Animal, 18: 1303-1316.

Mitchell, G.A.; F.T. Bingham and A.L. Page. 1978. Yield and metal composition of lettuce and wheat grown on soils amended with sewage sludge enriched with cadmium copper, nickel and zinc. $J$. Environ. Qual. 7: 165-170.

Mordy A. Atta-Aly. 1999. Effect of nickel addition on the yield of parsley leaves. $J r$. Scientia Horticulture. 82 (1-2): 9-24.

Muller, M. and Anke, M. 1994. Distribution of cadmium in the food chain (Soil planthuman) of a cadmium exposed area and the health risks of the general population. Science of the Total Environment. 156 (2): 151-158.

Nadia Gad, El-Sherif, M.H. and El-Gereedly, N.H.M. 2007. Influence of Nickel on some physiological aspects of tomato plants. Australian Journal of Basic and Applied Sciences, 1 (3): 286-293.

National Research Council (NRC) 1980. Mineral tolerance of domestic animals, National Academy of Sciences, Washington, D.C. pp. 577. 
Ni. W.Z.; Long. XX; Yang, XE. 2002. Studies on the criteria of cadmium Pollutia in growth media of vegetable corps based on the hygienic limit of cadmium in food. $J$. Plant Nutrition, 25 (5): 957-968.

Nriagu, J.O., 1989.A global assessment of natural Sources of atmospheric trace metals. Nature. 338 (6210): 47-49.

Olsen, S.R. 1972. Micronutrients interactions pp. 243-264. In J.J. Morvedt P.M. Giordano and Lindsay WL (ed.) Micronutrients in agriculture. Soil Sci. Soc. Am. Madison, Wisconsin.

Page, A.L. 1974. Fate and effect of trace elements in sewage sludge when applied to agricultural lands. Environ. Prot. Tech. Ser., EPA-620/2: 274-205.

Page, A.L.; Bingham, F.T. and Nelson, C. 1972. Cadmium adsorption and growth of various plant species as influenced by solution cadmium concentration. $J$. Environ. Qual., 1: 288-291.

Panes, V.G. and Sukhatme, P.V. 1967. Statistical method for Agricultural Worker, ICAR, New Delhi.

Parida, B.K; Chhibba, I.M. and Nayyar, V.K. 2003. Influence of nickel-contaminated soils on fenugreek (Trigeonella coriniculata L.) growth and mineral composition. Scienta Horticulturae, 98 (2): 113-119.

Parveen, Z; Khuhro, M.I. and Rafiq, N. 2003. Market basket Survey for lead, Cadmium, Copper, Chromium, nickel and Zinc in fruits and Vegetables. Bulletin of Environmental Contamination and Toxicology, 71(6): 1260-1264.

Patra, S.K and Das, J.S. 2006. Heavy metals toxicity of soils and corps in low lying land of Howghly River. Basin in India. Soil and Natural Haz and S. 89-4.

Piper, C.S. (1966). Soil and plant analysis. Inter Science Publ., New York.

Poschenrieder, C; Cabot, C. and Barcelo, J. 1983. Influence of high concentrations of cadmium on growth, development and photo-synthetic pigment of Phaseolus vulgaris. Anales de Edafologiay Agrobiologia. 42 (1/2): 315-327.
Ramani, V.P; Patel. K.P; Patel, K.C. Patel, B.K. and George, V. 2008. Effect of nickel and FYM on yield and chemical composition of spinach grown on effluent irrigated Fluventic ustochrepts of middle Gujarat. Ecology, environment and conservation. 14 (2-3).

Richards, L.A. Ed 1954. Diagnosis and improvement of saling alkali soils. Agric. Handb. U.S. Dep. Agric. 60.

Shentu, J.; Zhenli, He; Xiao, E. Yang and Tingqiang, Li 2008. Accumulation Properties of Cadmium in a selected Vegetable Rotation System of South eastern China. Journal Agric. Food Chem. 56 (15): 6382-6388.

Singh, A.K. and Rattan, R.K. 1987. A new approach for estimating the phytotoxicity limits. Environ. Monitoring and Assessment, 9: 269-283. (Cited) 1987 by D. Reidul Publishing Company.

Singh, A.P. 1985. Ph.D. Thesis, Deptt. of Soil Science RAU, Pusa, Bihar.

Singh, S.P. and Nayyar, V.K. 1994. Accumulation characteristics of cadmium and its upper critical levels in selected vegetable species. International Journal of Environmental studies. 36 (3): 199204.

Som, Shrabani., Gupta, S.K of Banarjee, S.K. 1994. Assessment of quality of sewage effluents from Howrah sewage treatment plant. J. India Soc. Soil Sci. 42 (4): 571575.

Souerback, D.R. and Hein, A. 1990. The nickel uptake from different soil and its prediction by chemical extractions. Water, Air and Soil pollution. Proc. an International Cong. Orlando, Florida, pp. 861-871.

Sterritt, R.M. and J.N. Lester 1980.The value of sewage sludge to agriculture and effects of the agricultural use of sludges contaminated with toxic elements. A Review. Sci. Total Envir. 16: 55-90.

Swaine, D.J. 1955. "The trace element content of soils", common wealth Bureau of soil science. Tech. common. 48. 
Turner, M.A. 1973. Effect of cadmium treatment on cadmium and Zinc uptake by selected vegetable species. J. Environ. Qual. 2: 118-119.

Udom, B.E., J.S.C. Mbagwu, J.K. Adesodun and N.N. Agbim 2004. Distribution of zinc. Copper, cadmium and lead in a tropical ultisol after longterm disposal of sewage sludge. Environ. Int. 30 (4): 467470.

Valdares, J.M.A.S.; Gal, M.; Mingelgrin, U. and Page, A.L. 1983. Some heavy metals in soils trated with sewage sludge, their effects on yield and their uptake by plants. J. Environ. Qual., 12: 49-57.

Vinogradov, A.P. 1959. "The Geochemistry of Rare and Dispersed Chemical Elements in Soil", Consult ants Bureau, New York.

Walkley, A. and Black, I.A. 1934. An examination of the Degtjareff method for determination of soil organic matter and proposed modification of the chromic acid titration method. Soil Science 37: 2938.

Wallace, A. 1980. Trace metal placement in soil on metal uptake and phytotoxicity. $J . P l$. Natr. 2: 35-38

Wallace, A. 1989. Plant responses to some hardly known trace elements and trace element composition and distribution in plants. Soil Sci. 147: 461-464.
Wang Lixia (1979). Heavy metal pollution of downstream of the Xiang Jiang River, Human Province. Journal of Geographical Sciences 18 (3): 352-362.

Yang-X, Baligar, V.C.; Martens, D.C.; Clark, R.B. 1996. Plant tolerance to nickel toxicity: influx, transpon and accumulation of nickel in four species. Journal of Plant Nutrition, 19 (1): 73-85.

Yargholi, B; Azimi, A.A; Baghvand, A; Liaghat, A.M. and Fardi, G.A. 2008. Investigation of cadmium Absorption and Accumulation in Different Parts of Some Vegetables. American-Eurasian Journal and environment Science. 3 (3): 357-364.

Zaniewicz-Baskoswa, R. Rosa, J. Franczuk, E. Kosterna 2007. Direct and Secondary effect of liming and organic fertilization on cadmium content in soil and in vegetables. Plant soil Environment.53 (11): 473-481.

Zdenek Poulik 1999. Influence of nickel contaminated soils on lettuce \& tomatoes. Scientia Horticulture 81 (3): 243-250.

Zurera-Cosano, G. Moreno-Rojas, R; SalmeronEgea. J, Pozo Lara, R. 1989. Heavy metal uptake from greenhouse border soils for edible vegetables. J Sci. Food Agric. 49 (3): 307-314.

\section{How to cite this article:}

Sunita Kumari, Ashwani Chandrawal, Manoj Kumar and Anand Kumar. 2018. Toxicity of Cadmium and Nickel in Soil and Vegetables. Int.J.Curr.Microbiol.App.Sci. 7(10): 2341-2352. doi: https://doi.org/10.20546/ijcmas.2018.710.271 